\title{
Dedikerte lærere med bål på timeplanen i videregående skole
}

\author{
Kristian Abelsen` og Petter Erik Leirhaug \\ Norges idrettshøgskole, Norge
}

\section{Sammendrag}

Bålet har en sentral plass i norsk friluftsliv, og bålet inngår ofte når friluftsliv står på timeplanen i norske skoler. Hvordan det arbeides med bål, hvorfor og hva bålet faglig skal bidra med, er det mindre kunnskap om. Denne artikkelen er inspirert av at alle lærerne som deltok i et aksjonsforskningsprosjekt valgte bålet som sentralt innhold i friluftslivsundervisningen uten at det er omtalt $\mathrm{i}$ læreplan eller var initiert av forskerne. Målet i artikkelen er å belyse bruk av bål i friluftslivsundervisning som del av kroppsøving i videregående skole og læreres og elevers erfaringer med dette. Selve aksjonsforskningsprosjektet ble gjennomført i dynamisk samarbeid mellom forskere og lærere som selv stod ansvarlige for undervisning og gjennomføring. Analysene i studien struktureres med utgangspunkt i den didaktiske trekant og bruker empiri fra kvalitative intervju med lærere og spørreundersøkelse blant elevene. I analysen framtrer bålet som stemningsskapende og et egenartet bidrag til læring i og gjennom friluftsliv i videregående skole. Bål som innhold synes å engasjere elever individuelt, som fellesskap og beskrives av ulike elever i spennet fra gøy til kjedelig, samtidig som det virker å skape mestringsopplevelser. Sentrale momenter i beskrivelser og lærernes refleksjoner drøftes som empiriske bidrag til bålets didaktikk.

Nøkkelord: friluftsliv; friluftslivspedagogikk; kroppsøving; fagdidaktikk; uteskoledidaktikk

\begin{abstract}
Dedicated teachers with campfire on the time schedule in Norwegian upper secondary school

The campfire is central in Norwegian Friluftsliv (cultural tradition of outdoor education and recreation) and figures often prominently when Friluftsliv is undertaken in Norwegian schools. However, little is known about the pedagogical work of the campfire - how and what the campfire can contribute to educational goals and learning outcomes. This article is inspired by the fact that all teachers participating in an action research project, chose the campfire as a central component in an outdoor education teaching module, even though the campfire is neither mentioned in the official curriculum nor initiated by the project researchers. The aim of the article at hand is to shed light on the pedagogy and instruction for outdoor education (in school) based on teachers' and students' experiences with the campfire in the context of friluftsliv teaching in upper secondary school physical education. The action research project itself was carried out as a dynamic collaboration between researchers and teachers who were themselves responsible for teaching and implementation. The analyses in this article are structured on the basis of the didactic triangle and
\end{abstract}

^Korrespondanse: Kristian Abelsen, e-post: kristiana@nih.no

(C) 2022 K. Abelsen \& P. E. Leirhaug. This is an Open Access article distributed under the terms of the Creative Commons Attribution 4.0 International License (https://creativecommons.org/licenses/BY/4.0/), allowing third parties to copy and redistribute the material in any medium or format and to remix, transform, and build upon the material for any purpose, even commercially, provided the original work is properly cited and states its license.

Citation: K. Abelsen $\mathcal{E}$ P. E. Leirhaug. «Dedikerte lecrere med bål på timeplanen i videregående skole» fournal for Research in Arts and Sports Education, Special issue: Friluftsliv, dannelse, laring og didaktikk, Vol. 6(1), 2022, pp. 21-36. 


\section{K. Abelsen \& P. E. Leirhaug}

use data from qualitative interviews with teachers and student questionnaires. Campfires as content in outdoor education seem to engage students both individually and as a community, are described by students both as fun and boring, and appear to create mastery experiences for students. Key elements in the teaching processes and teachers' reflections are identified as empirical contributions to the didactics of the campfire.

Keywords: friluftsliv; outdoor education; campfire; Physical Education; Norway

Mottatt: Mars, 2021; Antatt: November, 2021; Publisert: Januar, 2022

\section{Innledning}

Bålets plass i norsk friluftsliv er udiskutabel. Hyllemeter med inspirasjons- og kunnskapsbøker om bål og friluftsliv er skrevet (f.eks. Berg, 2015; Langåsdalen, 2016; Svardal, 2015; Winge \& Nohr, 2019). Vi fyrer nying slik norske skogsarbeidere har gjort i generasjoner (Norsk skogbruksmuseum, 1984). Vi lar oss fange av bålets meditative kraft og vi fascineres av samenes rike båltradisjoner (Murud, 2018; Ryd, 2018). Bålet er kilde til varme, hygge og rike sanselige minner som kaffegrut piplende ut av svartkjelen, eimen av brennende tyrirot, bålrøyken som irriterer, eller grillpølsene som danderes med kullsvart «krydder». Men bålet er ikke bare opplevelser og minner; som metafor og på bakgrunn av undersøkte psykologiske effekter er bålet benyttet terapeutisk i naturbaserte behandlingsopplegg (Beck, 2016; Corazon et al., 2011, 2018). «De syv kaffekok» er et eksempel på hvordan bålet tilsvarende giøres sentralt $i$ et samiskinspirert spirituelt entreprenørskap (Fonneland, 2012). Det er heller ikke tilfeldig at friluftslivsprofilen Lars Monsen $(1994,2017)$ valgte å ta med svartkjelen i tittelen når han skulle skrive bok om hva han har lært av villmarka og friluftslivet.

I skolesammenheng kan det også se ut som om bålet har en sentral plass når friluftsliv og uteskole i natur står på timeplanen. Flere av lærerinformantene i Jordets (2007) doktoravhandling om uteskole omtaler bålet som «friluftslivets sjel» og en uunnværlig del av uteskoledagen. Leseren får en rekke eksempler på hvordan bål og aktiviteter med og ved bålet blir omdreiningspunkt for konkrete læringsprosjekter. Det handler om hva som brenner, hvordan få fyr i bålet, ulike bål til ulike formål, gjeldende regler og gode tips, mat som kan tilberedes. Bakenfor vaker kulturhistorie om bål og sivilisasjon (Goudsblom, 1992; Gowlett, 2016) - historier om hvordan bålet har vært, og fortsatt er, kilde og forutsetning for en lang rekke formål og gjøremål. Om vi velger friluftsliv innunder kroppsøving i NDLA - Nasjonal digital laringsarena, finner vi fagstoff om bål. Vi finner både en klassisk tekst om båltyper (NDLA, 2019) og en video hvor Lars Monsen viser hvordan forberede og fyre bål (NDLA, 2012). Men bålet i skolesammenheng er mer enn ferdigheter og kunsten å få fyr. I boka Ncermiljøfriluftsliv $i$ skolen (Østrem, 2021) innleder Abelsen (2021) avsnittet om «Bålets didaktikk» med setningen: «Leirbålet inviterer til fortellinger, samtaler, samvær og ettertanke» (s. 59). 
Doktorgradsprosjektet til Sølvik (2013) undersøkte læringsressurser og læringspotensial i friluftsliv med utgangspunkt i en spesialskolekontekst. Friluftsliv framstår som en annerledes læringsarena for elever. Basert på observasjon og intervjuer, fremhever hun bålet som samlingsplass (s. 210) som en av fire sosiale læringsressurser sammen med kroppslig samhandling, miljøendring og voksenrolle: «Bålet framstår som ei samlande kraft i friluftsliv. Ungdommane gir uttrykk for eit særeige og sanseleg samvær rundt bålet, som igjen opnar for gode samtaler» (s. 228). Sølvik (2013) viser kvaliteter ved det non-verbale fellesskapet som kan oppstå når en sitter sammen rundt bålet, sanser og opplever. Elevene trekker fram at de har god tid, det er ro og de opplever at de prater om andre ting rundt bålet, noe også andre studier i skolen har vist (Abelsen \& Leirhaug, 2017; Leirhaug et al., 2020). Samtidig som Sølvik (2013) fester seg ved det hun tolker som en likeverdig og aktiv deltakelse i samtalen rundt bålet, skriver hun om hvordan fellesskapet for enkelte elever kan oppleves krevende og til og med ekskluderende. Dette er perspektiver vi tar med oss når vi i denne artikkelen vil bruke empiri fra et aksjonsforskningsprosjekt i kroppsøving i videregående skole til å belyse og drøfte didaktikk for friluftsliv (i skole) med utgangspunkt i læreres bruk av og elevers møte med bål i friluftslivsundervisning. Vi har latt oss inspirere av at alle lærerne som deltok i aksjonsforskningsprosjektet valgte bålet som sentralt innhold i friluftslivsundervisningen, uten at bål er omtalt i læreplan (Utdanningsdirektoratet, 2015) eller var et valg initiert av forskerne. Vi vil bruke den didaktiske trekanten (Künzli, 1998; Öhman, 2014) for å utforske rollen bålet får i oppleggene, hva lærerne og elevene sier om bålet, og drøfte hvilke didaktiske grep som synes vesentlige når bål står på timeplanen. En slik utforsking av bålets didaktikk inkluderer spørsmål relatert til det Tordsson $(2014$, s. 15, 19) kaller friluftslivets iboende pedagogikk og hva som eventuelt tilhører bålet som (unikt) innhold. Vi spør etter didaktiske overveielser, erfaringer og prosesser i relasjonene mellom lærer, elev og innhold når bål blir brukt i friluftslivsundervisning som del av kroppsøving i videregående skole.

Det viktige bidraget er det empiriske utgangspunktet med friluftsliv i videregående skole, ikke minst i lys av at forskning over tid har vist at elever på dette trinn i opplæringen knapt erfarer friluftsliv i kroppsøving (Abelsen \& Leirhaug, 2017; Leirhaug \& Arnesen, 2016). Teoretisk følger vi Gundem (2008) i at «didaktisk begrepsbygning er en følge av kontakt med praksis» (s. 12), og vil argumentere for at artikkelen representerer et empirisk bidrag til å forstå og utvikle friluftslivsdidaktikken. I det neste avsnittet vil vi redegjøre for utforskingens didaktiske og analytiske grunnlag, før vi deretter kommer tilbake til prosjektet, benyttet datamateriale og hva vi har funnet.

\section{Didaktikk og analytisk ramme}

Didaktikkens historie skrives tilbake til Comenius (1657/2008) og hans store verk Didactica Magna. Quennerstedt og Larsson (2015) viser til en bred internasjonal forståelse og skriver at didaktikk handler om relasjonen mellom undervisning, læring og sosialisering. Didaktikk beskrives gjerne som undervisningskunst (Gundem, 2008; 


\section{K. Abelsen \& P. E. Leirhaug}

Öhman, 2014); en praktikerorientert undervisningslære eller læren om undervisningens hva, hvordan og hvorfor (Engelsen, 2015; Quennerstedt, 2019). Felles for ulike teorier og tilnærminger er ønsket om å begi seg inn i og forstå mer av den kompleksitet som kjennetegner undervisning og læringsprosesser. Til grunn for våre analyser har vi tatt utgangspunkt i den didaktisk trekant (figur 1) slik den er presentert og anvendt av Öhman (2014) og Quennerstedt (2019).

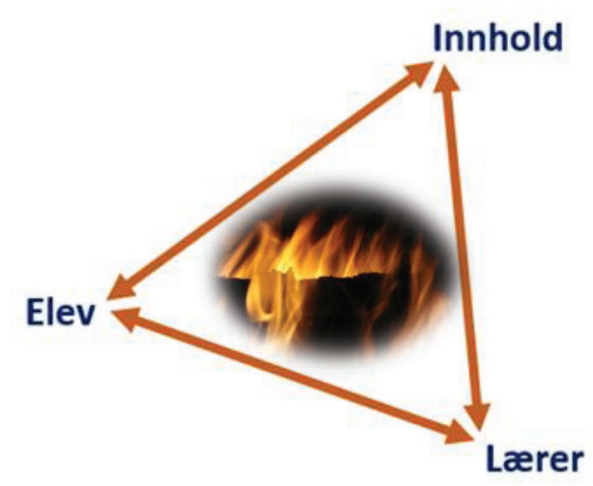

Figur 1. Den didaktiske trekant

Trekanten fremstiller visuelt hvordan de dynamiske relasjonene mellom elev, lærer og innhold er grunnleggende i didaktisk virksomhet og illustrerer hvordan innholdet, eller lærestoffet, ikke er noe for en gang gitt, men utformes i kommunikative prosesser. Innhold må derfor, som Gundem (2003) påpeker, bli forstått ut fra flere forhold, som kulturarv, samfunnets utvikling og krav, normer og verdier, men også det flerkulturelle, digitalisering, internasjonalisering og det globale samfunn. Her ligger mer eller mindre bevisste strukturer som bidrar for eksempel til at lærerne velger å fyre bål som del av innholdet når de skal ha nærmiljøfriluftsliv i kroppsøving. For å få grep om kompleksiteten som skapes ved kontekstuelle forhold som skolekultur og samfunnssystem, plasserer Öhman (2014) trekanten inn i et større rammeverk og omtaler da modellen som den utvidede didaktiske trekant (Hudson \& Meyer, 2011). Der Öhman (2014) kan sies å zoome ut mot de kontekster som fremmer eller hemmer ulike didaktiske valg og praksiser, vil vi zoome inn mot det som skjer i friluftslivsundervisningen, hva lærere og elever sier de gjør og erfarer når bål er en vesentlig del av innholdet.

Eleven kobler vi til spørsmål om utvikling og et åpent læringsbegrep hvor erfaringslæring og læring knyttet til sansning, forståelse, opplevelse og handling står sentralt. I likhet med Öhman (2014) står vi her i en læringsteoretisk tradisjon fra Dewey (1938). Nå er det slik at de fleste situasjoner i skolen er sosiale, og elevenes opplevelser, erfaringer og læring foregår i et fellesskap, hvilket gjør relasjonen elev-elev til en vesentlig dimensjon som ikke har noen egen plass i den didaktiske trekanten. Dette er en vanlig kritikk av modellen (Quennerstedt \& Larsson, 2015) som vi tar 
hensyn til i arbeidet med bålet. Vi har jo allerede sett hvordan bålet er fremstilt som samlende. Læreren konkretiseres i denne artikkelen til de medforskende lærerne i aksjonsforskningsprosjektet og deres arbeid, praksisbeskrivelser og refleksjoner. Mer generelt didaktisk-teoretisk knyttes lærer til sentrale forhold både relatert til lærestoffet, de ulike sammenhenger dette innholdet står i og til eleven og læringsmiljøet.

\section{Metode}

Artikkelen henter sin empiri fra et toårig aksjonsforskningsprosjekt i kroppsøving ved tre videregående skoler. Aksjonsforskningen handlet om å utvikle didaktikk knyttet til dans og friluftsliv i kroppsøving og utforske læreres og elevers erfaringer med dette. Dette mot en bakgrunn hvor kartleggingsstudier viser at dans og friluftsliv som faginnhold i liten grad realiseres, spesielt i ungdomsskole og videregående skole (Leirhaug \& Arnesen, 2016; Moen et al. 2018), selv om både dans og friluftsliv er tydelig i læreplanen for kroppsøving (Utdanningsdirektoratet, 2015). I skoleåret 2017-2018 ble det gjennomført en pilot hvor en medforskende lærer prøvde ut sammenhengende perioder med 12 timer dans og 12 timer friluftsliv i kroppsøving med en Vg1-klasse. Erfaringer fra pilotåret førte til valg av aksjonsforskning som design for det videre arbeidet (Kemmis et al., 2013), inkludert en beslutning om å videreføre rammen med 12 timer til dans og friluftsliv. Vi ønsket medforskende og autonome lærere som selv utviklet og gjennomførte det faglige innholdet basert på læreplanen (LK06) og skolens rammer. Premisser for friluftslivsdelen som utgjør grunnlaget i denne artikkelen, var orientering mot faglig dybde framfor variasjon, og at undervisningen i friluftsliv skulle utgjøre 12 timer for elevene gjennomført i en sammenhengende periode i høsthalvåret. Undervisningen skulle være nærmiljøbasert og lite ressurskrevende.

Tre videregående skoler ble rekruttert, og aksjonsforskningsprosjektet hadde oppstart skoleåret 2018-2019 med seks lærere og seks Vg1-klasser. Av ulike årsaker var det ikke mulig for to av lærerne å delta i prosjektets andre år, og utvalget i artikkelen er følgelig de fire lærerne ved tre videregående skoler som har fulgt prosjektet begge årene og de i overkant av 260 elever som har deltatt i friluftslivsundervisningen. Alle involverte, elever, lærere og skoleledelse, har gitt informert samtykke til deltakelse og prosjektet er godkjent av NSD, Norsk senter for forskingsdata.

Lærerne har fått de fiktive navene Ida, Kari, Simen og Vera. De kan beskrives som dedikerte lærere som ivrer for fagutvikling. Underveis har forskere og de medforskende lærerne møttes i ulike faser. Innledende handlet det om å forankre og klargjøre prosjektets idé og ambisjon. Dette ledet til konkrete behov for støtte og oppfølging, både $\mathrm{i}$ det praktiske og faglig. Workshop i friluftsliv er gjennomført i to omganger og representanter fra forskningsgruppen har deltatt på befaring i skolenes nærmiljø. I tillegg til avtalte møter, ideutveksling og løpende dialog om utvikling i aksjonsforskningsprosjektet, er en flermetodisk tilnærming benyttet for å innhente data, informere prosjektets videre utvikling og utforske og dokumentere erfaringer (Creswell, 2018; Kemmis et al., 2013). Til denne artikkelen er det data fra spørreskjemaundersøkelse 


\section{K. Abelsen E P. E. Leirhaug}

blant elevene og kvalitative individuelle sluttintervju med de fire lærerne som er lagt til grunn.

Spørreskjemaundersøkelsen var utarbeidet i verktøyet SurveyXact, og utforming av spørsmål bygde på Haraldsen (2012) og erfaringer med tilsvarende spørreskjema testet i piloten. Undersøkelsen, som består av 31 lukkede og ni åpne spørsmål, ble gjennomført digitalt i slutten av hvert prosjektår. 193 elever fullførte (svarprosent 72). Vi bruker i denne artikkelen bare påstanden «I år har jeg lært friluftsliv i kroppsøving» fra de lukkede spørsmålene der elevene rapporterte på femdelt Likert-skala, og av de ni åpne spørsmålene er det følgende to som har vist seg mest relevant for problemstillingen:

- Skriv om hvordan det var å ha friluftsliv i høst.

- Lærte du noe nytt i friluftslivsundervisningen? Beskriv hva du lærte.

En time lange intervju med hver av de fire lærerne ble gjennomført høsten 2020, etter at aksjonsforskningsperioden var avsluttet. Begge forfattere deltok på intervjuene som i stor grad hadde oppmerksomheten rettet mot erfaringer med å planlegge, gjennomføre og forfine undervisningsopplegg i friluftsliv. Det var semi-strukturerte kvalitative intervju, slik Kvale og Brinkmann (2015) beskriver. Intervjuene ble transkribert, og forfatterne leste grundig gjennom intervjumaterialet hver for seg.

Førsteforfatter gjorde en systematisering av alle utsagn som kunne relateres til bål og sorterte disse i tre hovedkategorier ut fra den didaktiske trekant, henholdsvis bål som faglig innhold, elevers og lereres erfaringer og kommentarer til bruk av bål. I tillegg inkluderte dette første analysearbeidet en fjerde kategori for beskrivelser av gjennomføring, både konkret om bålarbeidet i undervisningen og hvordan bålet inngikk i helheten. Forskerne gikk så sammen og drøftet sorteringen. Tilnærmingen følger Braun og Clarkes (2019) utlegning av refleksiv tematisk analyse. Først ble ulike utsagn om bål og relevante erfaringer og overveielser sett i forhold til hverandre og strukturert tematisk ut fra didaktisk eller innholdsmessig relevans. Elevmedvirkning og bålet som samlende er eksempel på slike tema som vil være gjenkjennbare i resultat- og drøftingsdelen. Gjennom en fram- og tilbake-bevegelse mellom tema og analysekategoriene identifiserte vi de grep, erfaringer og overveielser som ble tydeligst og tillagt mest vekt innenfor hver av kategoriene lærer-innhold, lærer-elev og elev-innhold. Utsagn opprinnelig plassert i en fjerde kategori for konkretisert arbeid med bål ble innpasset i de tre andre kategoriene. Deskriptiv analyse av det kvantitative materialet og elevers tekstsvar fra spørreskjemaundersøkelsen har vært vesentlig for kategorien elevinnhold, men har også bidratt med nyansering av lærernes perspektiv, tro og overveielser rundt bål som innhold. Det er selvsagt begrenset dybde i hva vi kan si om elevenes erfaringer ut fra deres skriftlige svar på en spørreskjemaundersøkelse. På den andre siden er det kun 9 av 193 elever som ikke har delt meningsfulle responser. Noen svarer ganske fyldig, andre med to ord, men totalen utgjør et relativt omfattende datamateriale som vi i hovedsak bruker til å løfte opp hovedlinjer i det elevene uttrykker. Videre skal det understrekes at det har vært aksjonsforskning med observasjoner, deling av erfaringer og dialog underveis, noe som har betydning for vår 
tolkning, forståelse og presenterte perspektiv på det vi med Abelsen (2021) kan kalle bålets didaktikk. Vi har hele tiden vært bevisst dette og prøvd å opprettholde en kritisk distanse ved hyppig å konferere datamaterialet og kontinuerlig drøfte egen rolle som forskere.

\section{Didaktiske funn og drøftinger}

Bålet som innhold er natur(lig)

Et første funn er bakgrunnen for denne artikkelen og valget alle lærerne i aksjonsforskningsprosjektet selv gjorde om å inkludere bålet som innhold i kroppsøvingsundervisning med friluftsliv. Videre at lærerne som gjennomførte med nye klasser i prosjektets andre år valgte å videreføre bål og videreutviklet bålopplegget som innholdskomponent. På spørsmål om hva eleven bør lære av friluftsliv i kroppsøving, sier Vera: «Å kunne lese kart og planlegge ting, også ikke minst fyre bål. Og lage enkel mat på bål. Og kunne litt om bekledning da, som egner seg.» Erfaringene som kommer til uttrykk og valget til lærerne kan tolkes som en felles tro på bålets magi, på gode prosesser rundt bålet og at ferdigheter og arbeid tilknyttet bål er viktig. Det er et bevisst valg, men like fullt virker det å være et valg lærerne ikke mener de trenger å argumentere pedagogisk for. Ikke ulikt informantene til Jordet (2010), som framhevet bålet som friluftslivets sjel og en unnværlig del av uteskoledagen.

Ilden og bålet har kanskje alltid vært der, like naturlig som vann, luft og jord, slik det for Aristoteles og de antikke filosofene ble oppfattet som ett av de fire elementene som alt dypest sett bestod av (Ball, 2002). Lærernes valg kan også settes i sammenheng med beskrivelser av bålet som bærer av tradisjoner, kultur- og sivilisasjonshistorie (Goudsblom, 1992; Gowlett, 2016). Håndbøker og kunnskapsbøker om bål og friluftsliv er raske med å peke på menneskets, genetisk sett, nære forhistorie som uteliggere og fangstfolk, prisgitt ildens mange "gaver», når de skal forklare hvorfor moderne innemennesker stadig tiltrekkes av bålet og ilden. Ida uttrykker at dette med overlevelse faktisk er noe å ta på alvor: «Ja, litt sånn seriøst også, for det er jo faktisk kunnskaper som du kan overleve på, å mestre bålfyring er en viktig ferdighet.» Å peke på overlevelsesferdigheter fra tidlige tiders naturnære kulturer og evolusjonistiske argumenter er ikke ukjent når friluftsliv skal grunngis i kontekster av opplæring og pedagogikk (f. eks. Faarlund, 1973; Hagen, 2000). Hos lærerne i prosjektet er ikke denne type argumentasjon sentral. Overveielsene om bruk av bål handler heller om å gi elevene opplevelser og enkle erfaringer med friluftsliv som kan vekke interesse, lyst og kanskje ønske om gjentakelse. Erfaringene er at bålet synes å bidra til denne type gode opplevelser for de fleste elevene, og lærerne uttrykker at bål er noe de vil ta med seg i arbeidet med å utvikle friluftsliv som del av kroppsøvingsundervisningen.

Fra hva til hvordan - læreren og elevene

Lærerne informerte elevene ved oppstart av skoleåret at de var med i et prosjekt, og delte hvordan kroppsøving kanskje ville bli litt annerledes enn det de var vant til. Men 


\section{K. Abelsen E P. E. Leirhaug}

også direkte knyttet til friluftslivsundervisningen er lærerne opptatt av god elev-lærerdialog og viser til hvordan tydelig forventningsavklaring er avgjørende for forutsigbar dynamikk og ønskede læringsutbytter. Kari og Vera prioriterer begge å ta med elevene ut i skolens umiddelbare nærskog for en forberedende prat om hva som venter. Vera sier:

Den forberedelsesøkta tror jeg er kjempeviktig. Det hadde vi jo med Vg1 i første runde og det hadde vi nå. Og da var vi borti skogen rett borti her og liksom, var ute og prata om friluftsliv og slikt.

Lærerne har på ulike måter innlemmet det å forberede elevene og samtidig løfte opp og drøfte ulike oppfatninger av friluftsliv som del av dette. Hvorvidt det er medbestemmelse og elevinvolvering kan diskuteres. Oppleggene har klare rammer, uttalte forventninger og læringsmål.

Hvordan formidles og konstrueres så innholdet bål gjennom undervisningen og i interaksjoner mellom lærer og elev(er)? Vi har valgt å følge Simen og klassen ut, men vektlegger det som har framkommet i analysene av hele bålmaterialet. Simen, som selv har bred friluftslivserfaring, gjorde noen endringer fra første til andre år i prosjektet. Første året prøvde han å presentere et mat-på-bål-konsept med «litt sånn spennende retter og sånn", men erfarte at dette ikke engasjerte elevene. Dette førte til noe enklere matprosjekter i andre år, hvor elevene har «fått bestemme det sjøl da», noe Simen uttrykker at de opplagt setter pris på. Tabellen nedenfor er basert på Simens dokumenterte undervisningsopplegg. Den gir en oversikt over undervisningsforløpet i det andre året av prosjektet.

\begin{tabular}{|c|c|}
\hline Hva & Hvordan \\
\hline Forberedelse & $\begin{array}{l}\text { Samtale med elevene ved skolestart } \\
\text { Informasjonsskriv }\end{array}$ \\
\hline $\begin{array}{l}\text { Økt 1. Ut på tur. Tema: Finne ved. Etablere } \\
\text { bålplass. Få opp et bål. Lage pannekaker på } \\
\text { bål. Opprydning og sporløs ferdsel. }\end{array}$ & $\begin{array}{l}\text { Oppsøke nærmiljø. Kort instruksjon/veiledning. } \\
\text { Inndeling i små grupper. Samarbeid, prøving og } \\
\text { feiling. Avslutte med å oppsummere og forlate } \\
\text { området sporløst. }\end{array}$ \\
\hline $\begin{array}{l}\text { Økt 2. Ut på tur. Tema: Finne ved. Etablere } \\
\text { bålplass. Få opp et bål. Selvvalgt mat på bål. } \\
\text { Opprydning og sporløs ferdsel. }\end{array}$ & $\begin{array}{l}\text { Oppsøke samme nærmiljø. Jobbe videre i små } \\
\text { samarbeidsgrupper. Repetisjon. Øving. Men også } \\
\text { instruksjon og veiledning underveis. Avslutte med å } \\
\text { oppsummere og forlate området sporløst. }\end{array}$ \\
\hline $\begin{array}{l}\text { Økt 3. Ut på egentur i hjemmelekse. Tema: Enkel } \\
\text { turplan, finne fram, finne ved, få opp bål, } \\
\text { grille pinnebrød på bål. Opprydning og } \\
\text { sporløs ferdsel. }\end{array}$ & $\begin{array}{l}\text { Elevene oppsøker sin nærskog/nærmiljø i små } \\
\text { samarbeidsgrupper. De utarbeider felles turplan: } \\
\text { turmål, finne ved, lage bål, grille pinnebrød på } \\
\text { bål. Sporløs ferdsel. Elevene er selvstendige og får } \\
\text { anledning til å repetere, øve og samarbeide. }\end{array}$ \\
\hline Rapport/refleksjonsnotat & $\begin{array}{l}\text { Elevene utarbeider kort rapport gruppevis om hva } \\
\text { de har lært, refleksjoner ut fra mat på bål, bilder av } \\
\text { egen tur. }\end{array}$ \\
\hline
\end{tabular}


Elevsamarbeid i små grupper er noe vi finner igjen i alle oppleggene med bål. Simen viser selv til samarbeidslæring (Johnson et al., 2001) og sier at grupper på tre eller fire er gunstig, det blir "en sånn fin liten gruppe». Simen synes et slikt opplegg passer spesielt godt med elever som i utgangspunktet ikke kjenner hverandre. Det blir ansvarsfordeling, de prater, de ordner, de må samarbeide, og Simen opplever at elevene utvikler en type gruppetilhørighet. Bålet har en positiv innvirkning på det sosiale i klassen, noe som resonerer godt med elevenes egne tilbakemeldinger og den lille kunnskapen vi har om elevers erfaring med friluftsliv i skolen (Abelsen \& Leirhaug, 2017).

I Simens opplegg er det de praktiske prosjektene omkring bålet som dominerer, og vi ser hvordan bålet som innhold medfører en rekke oppgaver knyttet til fasene planlegging, gjennomføring og bearbeiding, noe som for elevene er med å skape progresjon og varighet. Simen erfarte hvordan medbestemmelse (valg av mat på bål) hadde innvirkning på motivasjon og engasjement. Det som ved første øyekast fremstår som et lærerstyrt og velregissert opplegg synes på flere måter å åpne for autonomi og elevenes mulighet for selvstendige valg. En elev formulerer det slik: «Jeg syns det var veldig gøy og lærerikt fordi vi var veldig selvstendige og læreren ikke trengte å passe på oss.» Flere av elevene uttrykker hvordan de opplever å bli ansvarliggjort og erfarer umiddelbar betydning av egne handlinger i møtet med et levende bål.

Kari har erfart hvor meningsfullt det kan være for elevene å oppleve mestring av både bruk av øks og det å få fyr i et bål:

Så sto jeg og observerte en jentegjeng som var på den båloppgaven. Og dem sto med
øks og liksom, "oi, det her var jo kult», liksom, "det her har vi ikke prøvd før». Og
jeg så at dem liksom ble overrasket over at dem klarte å håndtere en øks. Og dem
ble stolte og liksom, ble veldig ivrige da. Også klarte dem å få fyr på bålet så, hørte
jeg dem prata om at det, "kanskje vi skal dra ut og fyre bål en kveld og overnatte»
og liksom «ja, det gjør vi, vi kan faktisk klare det». [Ler] Det visste dem ikke, at dem
kunne klare det.

At elevene uttrykker at de «faktisk kan klare det» er interessant, ikke minst i lys av det langsiktige formålet i faget kroppsøving om livslang aktivitetsglede. Elevene møter et friluftslivsfaglig innhold som gir rom for øving, mestring og forhåpentligvis opplevelser og erfaringer som, i tråd med de dedikerte lærernes målsettinger og tro, ansvarliggjør og nører opp om en interesse. Ennå er det selvsagt langt igjen før vi kan snakke om den type friluftsliv literacy som Lyngstad og Sæther (2021) finner når de studerer elevers læringsutbytte på linjer med friluftsliv fordypning i videregående skole, men som Ida uttrykker: «yes, dette er noe de vil ønske å giøre igjen.»

Ida er den av lærerne som sterkest fremhever det vi kan kalle bålets psykologiske kvaliteter for den enkelte og hvordan det kan virke roende og samlende for klassen. For henne gir samlingen rundt bålet en anledning til å se og snakke med elevene på en annen måte. Ida beskriver hvordan elevene faller til ro. Bålet blir en naturlig samlingsplass, slik Sølvik (2013) beskriver, et rom for fritt sanselig nærvær og gode samtaler. Ida understreker at hun har få elever som har særlig erfaring med friluftsliv 


\section{K. Abelsen \& P. E. Leirhaug}

fra tidligere. Flertallet av elevene ved skolen har flerkulturell bakgrunn. For å møte elevene «hjemme» er Ida tydelig på at hun må vektlegge mestring, korte turer og kosen ved friluftslivet. Hun argumenterer for at bål som innhold er velegnet og fremmer målsettingene:

Jeg syns det giør så mye med stemninga på turen da, at det hvert fall, det blir en helt annen tur når man sitter rundt bålet og særlig hvis det er litt mørkt og. Man får en helt annen sånn kos og nær, mer nærhet kanskje, til naturen føler jeg.

Bålet fremstilles som en aktør som inviterer og bidrar til sanselig nærvær hvor en unik stemning oppstår. Denne egenarten eller kvaliteten ved bålet kan argumenteres å være et sentralt tilfang til bålets didaktikk i lys av det Tordsson (2014) omtaler som friluftslivets iboende pedagogikk. Ifølge Ida treffer dette elever uavhengig av erfaringsbakgrunn og kulturell tilhørighet. Ida uttrykker hvordan hun erfarer at elevene snakker om "helt andre ting» og at de på den måten «blir kjent på en helt annen måte». I vårt materiale er det få elever som uttrykker seg om denne dimensjonen, men det trenger ikke bety at de ikke har erfart den. Det kan like gjerne skyldes måten spørsmålene i spørreundersøkelsen er stilt på, og at elevene ikke inviteres til å skrive om denne dimensjonen. På spørsmål om læringsutbytte vektlegger de fleste elevene nyvunnen kompetanse i form av konkrete ferdigheter og kunnskaper. Det å skulle artikulere psykologiske og sanselige erfaringer som læringsutbytte med bål som innhold er sannsynligvis ganske fremmed for elevene, særlig når det hverken er tematisert eller konkret etterspurt. Samtidig er det mange elevstemmer som verdsetter den sosiale dimensjonen, men da i mer generelle vendinger. En elev skriver: «Bål og friluftsliv kan være en hyggelig og sosial aktivitet og brukes til å bli kjent med andre.»

Simen uttrykker at han er fornøyd med innholdet hvor arbeidet med bål gir anledning til repetisjon og øving på bål innenfor relativt avgrensede rammer. Ida sier at «fordelen med at de ikke kan så mye fra før av, er jo at det de føler veldig stor mestring da, når de får til å tenne bålet uten papir», og vender liten erfaring til noe positivt. «Det å få fyr på bål, det er jo kjempemestring», sier Simen, men er rask med å presisere at «de er jo ikke viderekomne i det hele tatt, det holder jo ikke med tre ganger». Lærerne legger vekt på hvordan elever opplever mestring, enten det er bålet de får fyr på, kubben de klarer å kløyve eller pannekakene de klarer å steke.Vi ser at når lærerne går fra valg om å arbeide med bål til hvordan, så er det de praktiske oppgavene som dominerer. Men et mangfold av slike oppgaver, skal det tillegges.

Simen sitt opplegg var det mest omfattende med tanke på bålet som innhold. Hos Kari og Vera inngikk bål som ett av flere innholdselementer. Ida har tonet ned ferdighetsaspektet og funnet det hensiktsmessig å ta med «ferdigved» fra skolen. Dette er en side ved opplegget hun ønsker å utvikle: «Jeg har hatt lyst til at vi lager bål med materialer fra naturen. Det er det neste jeg kunne egentlig tenkt meg å gå litt videre på.» Dette kan være et større grep enn hva en umiddelbart tenker. Ikke gjelder det bare å finne tørt virke i skogen, en må kanskje avklare med grunneier og sikre at tiden tillater et opplegg som gir elevene anledning til å faktisk oppdage, gjenkjenne, sage og hugge. 
Prosjektet har lært oss at denne type små endringer er frukter av å jobbe systematisk over tid. Felles for alle fire lærerne er innstillingen om å få til små endringer underveis. Fra første til andre prosjektår har Simen gjort små endringer for å sikre et mer relevant og realistisk innhold og opplegg for elevene, Kari og Vera har gjort endringer fordi de ønsket at elevene skulle få erfare å få fyr på egne bål, mens Ida snakker om hvordan hun i tiden som kommer kan forfine opplegg for å berike læringsutbyttet for elevene.

\section{Gøy med bål - eleven og innholdet}

Av de 193 elevene som har svart på spørreskjema sier $57 \%$ seg helt enige og $29 \%$ seg litt enige i at de har lært friluftsliv gjennom oppleggene. Gjennomgående i elevutsagnene er det slående hvor mange som uttrykker at de har lært noe om bål. Figur 2 viser et knippe sitater:

Lærte å tenne fire ulike bål

Lærte ulike tips og triks på å tenne bål
Lærte om gode ting i naturen som er tennbart

Lærte hvordan man skal bygge opp et bål

Lærte hvordan man skal bygge opp og tenne bål til forskjellig mat

Lært å lage ordentlig bål

Lært hva man ofte kan gjøre feil

Lærte hva slags ved man kan bruke

Figur 2. Utvalgte sitater om bål fra elevers svar på spørsmålet «Lærte du noe nytt i friluftslivsundervisningen? Beskriv hva du lærte»

Uten at materialet gir grunnlag for å drøfte dypere elevenes læring eller hva elevene forstår med læring, kan vi se en retning hvor elevene er opptatt av de praktiske sidene ved bålet. Som tidligere nevnt, og ikke ulikt de innledningsvis nevnte håndbøker $\mathrm{i}$ friluftsliv, trekker elevene fram konkrete ferdigheter og kunnskaper nødvendig for å mestre bålfyring og matlaging på bål. I tillegg trekker flere fram betydningen av det sosiale, og noen gir uttrykk for at de har verdsatt selvstendigheten og muligheten til å lære av hverandre: "At det var såpass god stemning selv om det var kaldt, og at klassen jobbet sammen og lærte bort ting og hjalp hverandre.» Men dette er ikke hele bildet. For eksempel reflekteres det å gjennomføre friluftsliv som hjemmelekse variert i materialet. I spørreundersøkelsen er det flere elever som uttrykker at det var krevende: «Det var ikke så lett å måtte dra på den turen i skogen utenom skolen, tror det skulle ganske mye til for at folk tok det seriøst.» At elever engasjeres ulikt er ikke nytt eller overraskende i skole- og undervisningssammenheng, men illustrerer hvordan invitasjonene som følger med friluftslivets og bålets iboende kvaliteter i seg selv ikke er nok. Didaktisk bærer bålet kvaliteter og mulighetsbetingelser som må ledsages av en nærværende pedagog, en som vet å forberede og «nøre opp den gode ild». Det være 


\section{K. Abelsen EO P. E. Leirhaug}

seg i form av forventningsavklaring og forberedelser, større grad av medbestemmelse eller oppgaver som enda tydeligere ivaretar, forplikter og engasjerer hele elevgruppen.

Når det er sagt, finner vi blant elevstemmene eksempler på elever som tar innover seg bålets historie som overlevelsesferdighet og peker på nytten og verdien av å kunne lage bål: «Man vet aldri når man får bruk for det og derfor syns jeg at det var greit å lære å lage f.eks. bål.» En annen elev er mer generell: «Det var veldig gøy å ha friluftsliv. Jeg lærte masse nytt som kommer til å være til nytte resten av livet.» Gøy og kjedelig er ord elevene virker å gripe til når de skal svare på hvordan det var å ha friluftsliv. Det er en klar overvekt blant elevene som sorterer til siden for gøy, hvor dette er et typisk elevutsagn: «Det var gøy å være ute og å lære om hvordan man kunne tenne bål.» Enkelte nyanserer og utfyller med for eksempel at det «var gøy å ha litt ansvar selv, lage mat og lage bål selv». Opplevelse av progresjon og det å mestre del(gjøre)mål virker å være gjennomgående erfaringer hos elevene som gir uttrykk for bål og læring som gøy. Kjedelig koples på den andre siden til oppgaver som oppleves lite utfordrende og beskrivelser som at det var «kaldt», «mye bål», «slitsomt» og «irriterende med bållukt».

Der bålopplegget for noen elever øker forståelsen og gir mestring ved at de får fyre bål gjentatte ganger, kommer det også fram at tre turer med bål for andre oppleves som kjedelig repetisjon og ensformig. En elev skriver det slik: «Det ble litt mye bål, kunne tenke meg litt lengre turer.» Men ikke alle er enige: «Vi hadde det noen få ganger så var ikke for lenge til at man ble lei.»

Tross enkelte motstemmer, så er gjennomgangstonen i elevenes utsagn knyttet til bål og erfaringer med bålopplegg positive. Som tidligere eksemplifisert handler det om at de uttrykker å ha lært noe nytt om bål, kjent på mestring og at bålet bidrar til det sosiale og et samvær som oppleves annerledes. Dette understøttes av lærernes overveielser og uttrykte erfaringer.

\section{Oppsummerende drøfting}

Med empiri fra et aksjonsforskningsprosjekt har målet i denne artikkelen vært å belyse friluftslivsdidaktikk med utgangspunkt i den didaktiske trekant og bål brukt $\mathrm{i}$ friluftslivsundervisning som del av kroppsøving i Vg1. Vi har sett hvordan dedikerte lærere ved tre skoler og deres elever har gitt uttrykk for erfaringer og overveielser etter arbeid med bål og bålfyring som del av et sammenhengende undervisningsopplegg på 12 timer. Dette representerer en empirisk inngang til å forstå og utvikle friluftslivsdidaktikk og bruk av bål i en skolekontekst.

Beskrivelser og lærerrefleksjoner fra studiens tre skoler viser hvordan bålet omtales som stemningsskapende og på ulike måter blir utgangspunkt for konkrete læringsog samarbeidsprosjekter. Flertallet av elevene, på tvers av skolene, uttrykker positive erfaringer med undervisningen og sier de har lært noe om bål og bålfyring. Av didaktiske grep som virker vesentlige for at et flertall av elever uttrykker seg positivt om erfaringer og læringsutbytte, er de fleste å regne som kjente pedagogiske og 
allmenndidaktiske grep (Engelsen, 2015; Tordsson, 2014). Det gjelder betydningen av elevmedvirkning, forventningsavklaring, mindre grupper elever som samarbeider om felles oppgaver og konkretiserte læringsmål som gir rom for å oppleve utvikling og mestring innenfor disponibel tidsramme. På den andre siden presenteres og erfares bålet i beskrevne prosesser og lærernes overveielser som et innhold med egne kvaliteter som på ulike måter kan finne gjenklang hos elever. Bålet blir et mål og læringsemne i seg selv. Det å «få opp et bål» aktualiserer en rekke grunnleggende friluftslivskunnskaper og ferdigheter. Hva er brennbart virke? Hvilke prinsipper må ligge til grunn for å skape ild? Hvilke båltyper egner seg til hvilke formål, og hvordan utøves bålfriluftsliv på en skånsom måte for naturen? Tilsvarende inviterer prosjektet til øving og mestring av ferdigheter med redskaper som kniv, øks og sag. Mangfold av oppgaver og utfordringer åpner for samarbeid og samhandling mellom elevene. Gjennom egne handlinger medvirker elevene i skaping av et innhold med smak, temperatur, farge, lukt og lyd. Bålet blir en aktør som bidrar med unike kvaliteter til fellesskapet, samtidig som det aktualiserer og gjør andre lærings- og danningsmål i kroppsøving og skole relevante.

Noe av hemmeligheten i en bålets didaktikk er kanskje at helheten er mer enn summen av delene, og at det bare er ved å fyre bål en kan vekke bålets mulige magi og levendegjøre dets pedagogiske potensialer. Analysene våre får fram hvordan bålet kan bli sentreringspunkt for praktisk organisering, (mat)fellesskap og det som omtales som et annerledes samvær og naturnærvær. Selv i skolesammenheng, med nærmiljøet som ramme, en stor gruppe elever og avgrenset tid, kan en slik unik stemning og atmosfære samskapes når lærere gjør bålet til aktør i det pedagogiske arbeidet. Men det framkommer også hvordan det å lykkes krever planlegging og ambisjon og vilje til å utvikle og forfine over tid. Gode forberedelser, inkludert forventningsavklaring, synes avgiørende når friluftsliv skal gjennomføres i en tidsavgrenset skoleramme. Bålet alene vil ikke kunne forhindre at elever kan kjenne seg ekskludert eller melder seg ut, noe Sølvik (2013, s. 143) beskriver i sitt doktorgradsprosjekt. Vår studie har ikke eksempler på denne type eleverfaringer, noe vi muligens ville fått med annen datakilde enn spørreskjema. Gjennomgående er at elevene verdsetter sosialiseringen som erfares på en ny arena, og det framkommer at elevene snakker om andre ting rundt bålet. Ida forteller om elever som blir kjent på en ny måte. Når vi vet at bål nyttes som terapeutisk virkemiddel for nærværs- og oppmerksomhetstrening (Beck, 2016; Corazon et al., 2011, 2018), er det ikke å regne som overraskende at denne type dynamikk kan inntreffe i skolesammenheng.

Fellesoppgaver med bålfyring støtter opp om sosiale mål i skolen. Det skaper hygge, nærvær, samhandling og trivsel, men også «irriterende bållukt» og fører til frustrasjon hos enkelte elever. Sitte sammen og kjenne på varmen, lukten, det sanselige nærvær, er det ikke slik da, at «irriterende bållukt» kan være et viktig erfarings- og læringsfenomen. Et av Deweys (1938) hovedpoeng ved læring er at erfaringen bringer oss ut av det vante og inn i «inquiry» med omgivelsene. Dyp eller varig læring forutsetter hos Dewey at erfaringen følges av refleksjon. Det autentiske i møtet med bålet er viktig å 
legge merke til, noe både Jordet (2007) og Sølvik (2013) poengterer tilsvarende. For elever som opplever bålet relevant som en overlevelseskompetanse, vil «irriterende bållukt» være noe av det som følger med når en skal lære noe som en kan ha nytte av resten av livet. Elever kan også lære at dette synes mange er kjekt og viktig, men det er ikke noe for meg. Dette er didaktiske overveielser oppleggene i prosjektet ikke reflekterer, muligens fordi lærerne sterkt vil bidra til livslang friluftslivsglede, og ser gode opplevelser som viktigste bidrag til dette?

Det som derimot fremtrer $\mathrm{i}$ analysen av didaktiske prosesser, er betydningen av dialogen med elevene, forventningsavklaring og at små deloppgaver er en nøkkel til mestringsopplevelser. Fiskum og Husby (2014) poengterer i boken Uteskoledidaktikk betydningen av å begrense nyhetsgapet som følger med å flytte undervisning ut og for mange bort fra det kjente og trygge. Elevene i dette prosjektet er gjennomgående lite vant med friluftsliv, noe som også fører over til et spørsmål om progresjon i utdanningsløpet som ikke lærerne stiller i tilknytning til mestringsopplevelsene. De didaktiske grunnspørsmålene hvorfor-hva-hvordan må suppleres med spørsmål som når og med hvem. Dette prosjektet er gjennomført med elever på Vg1. Med tanke på progresjon i skolefriluftslivet, uteaktivitet og friluftsliv i kroppsøving, er det rimelig å spørre om elever burde kunne finne ved og fyre bål, og mer generelt tilberede og innta mat under ferdsel og opphold i natur, før de kommer til Vg1?

Kompetansen å kunne planlegge og gjennomføre turer i natur med overnatting ute er noe elever ifølge læreplan i kroppsøving skal mestre på egen hånd etter 10. trinn. Sammen med andre fag og overordnete målsettinger i opplæringen er det ønskelig at skoler legger til rette for at elevene får opplevelser og erfaringer fra turer der en overnatter flere netter. Målet om å selvstendiggiøre elevene er sentralt både i læreplanen og hos lærerne i prosjektet. Erfaringene fra prosjektet indikerer at hjemmelekse som arbeidsmetode kan bidra til dette. Samtidig avdekker studien elever som har utfordringer med å ta slike selvstendige oppgaver «seriøst». Det er sannsynlig at et slikt pedagogisk grep krever en type modenhet som må etableres over lengre tide enn hva et 12 timers opplegg på $\mathrm{Vg} 1$ gir anledning til. Vektlegging av prosessen med turplan i forkant virker avgiørende. Her har lærer anledning til å følge opp og konkret veilede mot høy måloppnåelse. Dersom hjemmelekse som konsept er noe elevene møter ved flere anledninger, vil lærer ha mulighet til nettopp å speile elevene på både krav og utførelse.

Lærerne vi har beskrevet som dedikerte gir uttrykk for at friluftsliv krever en type merinnsats i planlegging. Det handler både om å utvikle og videreutvikle sammenhengende undervisningsforløp, og forberedelser til de praktiske oppleggene. Iver og merinnsats kan opplagt tilskrives at lærerne har deltatt $\mathrm{i}$ et forskningsprosjekt, men det er interessant å merke seg at de uttrykker at de gjennom prosessen har innarbeidet arbeidsmåter som vil giøre det enklere når de i framtiden skal gjennomføre tilsvarende. På spørsmål om framtiden, svarer alle fire at prosjektet har medført en tilnærming til friluftslivsundervisning som de vil bygge videre på. Friluftsliv i kroppsøving og skole er mer enn tekniske ferdigheter og kunnskaper. Erfaringen med bålrøyk og å kjenne på varmestråling fra flakkende flammer tilhører bålets didaktikk. 
Denne innsikt i betydningen av friluftslivsdidaktikkens hva peker mot et grunnleggende behov for å drøfte hvilke erfaringer og kompetanser det er viktig at elever får med seg fra friluftsliv i skole og kroppsøving. Kanskje er det slik at alle elever i norsk skole bør ha fått mulighet til å lære å fyre bål, sitte sammen med andre rundt et bål og gjøre erfaringer med tilberedning av mat på bål. I så fall er denne artikkelen et bidrag på veien til å finne ut hvordan dette kan gjøres meningsfullt og relevant.

\section{Forfatteromtale}

Kristian Abelsen er ansatt som universitetslektor ved Norges idrettshøgskole, institutt for lærerutdanning og friluftslivsstudier. Han underviser i friluftsliv på bachelorprogrammene friluftsliv og faglærer i kroppsøving og idrettsfag. Kjerneområdene for undervisning og forskning er friluftsliv i skolen, uteskole og didaktikk for langsomt friluftsliv.

Petter Erik Leirhaug er ansatt som førsteamanuensis ved Norges idrettshøgskole, institutt for lærerutdanning og friluftslivsstudier. Han underviser på bachelor- og masterprogrammene innenfor lærerutdanning og friluftsliv. Forskning er knyttet til kroppsøving, idrettsfag og friluftsliv i skolen, friluftslivsdidaktikk, lærerutdanning, vurdering i kroppsøving og læreplanutvikling.

\section{Referanser}

Abelsen, K. \& Leirhaug, P. E. (2017). Hva vet vi (ikke) om elevers opplevelser med friluftsliv i norsk skole en gjennomgang av empiriske studier 1974-2014. Fournal for Research in Arts and Sports Education, 1(3), 18-31. https://doi.org/10.23865/jased.v1.615

Abelsen, K. (2021). Leirliv, basisferdigheter og langsomt friluftsliv. I K. Østrem (Red.), Ncermiljøfriluftsliv $i$ skolen (s. 44-73). Cappelen Damm Akademisk.

Alrø, H. \& Hansen, F.T. (Red.). (2017). Dialogisk aksjonsforskning i et praksisncert perspektiv. Aalborg universitetsforlag.

Ball, P. (2002). The elements: A very short introduction. Oxford University Press.

Beck, M. A. (2016, 15. juli). Hvorfor er det så hyggelig med bål? https://forskning.no/psykologi-spor-en-forsker/ hvorfor-er-det-sa-hyggelig-med-bal/408175

Berg, Ø. (2015). Bålet - fra gnist til ild. Cappelen Damm.

Braun, V. \& Clarke, V. (2019). Reflecting on reflexive thematic analysis. Qualitative Research in Sport, Exercise and Health, 11(4), 589-597. https://doi.org/10.1080/2159676x.2019.1628806

Comenius, J. A. (1657/2008). Didactica Magna. Stora undervisningsläran. Studentlitteratur.

Corazon, S. S., Schilhab, T. \& Stigsdotter, U. K. (2011). Developing the therapeutic potential of embodied cognition and metaphors in nature-based therapy: Lessons from theory to practice. Fournal of Adventure Education $\mathcal{E}$ Outdoor Learning, 11(2), 161-171. https://doi.org/10.1080/14729679.2011.633389

Corazon, S. S., Sidenius U., Katrine Schjødt Vammen, K. S., Klinker, S. E., Stigsdotter, U. K. \& Poulsen, D. V. (2018). The tree is my anchor: A pilot study on the treatment of BED through nature-based therapy. International fournal of Environmental Research and Public Health, 15(11), 2486. https://doi.org/10.3390/ ijerph 15112486

Creswell, J. W. (2018) Research design. Qualitative, quantitative and mixed methods approaches. Sage.

Dewey, J. (1938). Experience and education. The Macmillan Company.

Engelsen, B. U. (2015). Kan lering planlegges? (7. utg.). Gyldendal Akademisk.

Fiskum, T. A. \& Husby, J. A. (Red.). (2014). Uteskoledidaktikk: Ta med fagene ut. Cappelen Damm Akademisk.

Fonneland, T. (2012). "De syv kaffekok» - spirituelt entreprenørskap i eit samisk landskap. Tidsskrift for kulturforskning, 11(2), 27-44. http://ojs.novus.no/index.php/TFK/article/view/654 


\section{K. Abelsen $\mathcal{G}$ P. E. Leirhaug}

Faarlund, N. (1973). Friluftsliv: hva-hvorfor-hvordan (Kompendium 32). Norges idrettshøgskole.

Goudsblom, J. (1992). Fire and civilization. Penguin.

Gowlett, J. A. J. (2016). The discovery of fire by humans: A long and convoluted process. Philosophical Transactions of the Royal Society B, 371(20150164), 1-12. http://dx.doi.org/10.1098/rstb.2015.0164

Gundem, B. B. (2003). Skolens oppgave og innhold: En studiebok i didaktikk (4. utg.). Gyldendal Akademiske Forlag.

Gundem, B. B. (2008). Didaktikk - fagdidaktikk, anstrengte eller fruktbare forhold? Acta Didactica Norge, 1(2), 1-14. https://doi.org/10.5617/adno.1020

Hagen, T. L. (2000). Friluftslivets opprinnelse. I K. Furuset (Red.), Ut, naturligvis! Barn, natur og uteaktiviteter (s. 9-21). Dronning Mauds Minne.

Haraldsen, G. (2012). Måleinstrumenter i spørreskjemaundersøkelser. Tidsskriftet den Norske Lageforening, 132(6), 616-617. https://doi.org/10.4045/tidsskr.12.0175

Hudson, B. \& Meyer, M. A. (Red.). (2011). Beyond fragmentation: Didactics, learning and teaching in Europe. Barbara Budrich.

Johnson, D. W., Johnson, R. T. \& Holubec, E. J. (2001). «Som hånd i hanske»: En praktisk innføring $i$ samarbeidslcering. Pedagogisk psykologisk forlag.

Jordet, A. N. (2007). "Narmiljøet som klasserom» - en undersøkelse om uteskolens didaktikk $i$ et danningsteoretisk og erfaringspedagogisk perspektiv [Doktoravhandling]. Universitetet i Oslo.

Kemmis, S., McTaggart, R. \& Nixon, R. (2013). The action research planner: Doing critical participatory action research. Springer Science \& Business Media.

Kvale, S. \& Brinkmann, S. (2015). Det kvalitative forskningsintervju (3. utg.). Gyldendal norsk forlag.

Künzli, R. (1998). The common frame and the places of Didaktik. I B. B. Gundem \& S. Hopmann (Red.), Didaktik and/or curriculum (s. 29-45). Routledge.

Langåsdalen, O. (2016). Den lille praktiske bålboka. Kolofon Forlag.

Leirhaug, P. E. \& Arnesen, T. E. (2016). Friluftsliv - et hovedområde i kroppsøvingsfaget? I A. Horgen, M. L. Fasting, T. Lundhaug, L. I. Magnussen \& K. Østrem (Red.), Ute! Friluftsliv - pedagogiske, historiske og sosiologiske perspektiver (s. 129-152). Fagbokforlaget.

Leirhaug, P. E., Grøteide, H., Høyem, H. \& Abelsen, K. (2020). Naturopplevingar, miljøbevisstheit og livsmeistring i vidaregåande skule. Kan 12 timar friluftsliv gjere ein skilnad? Norsk pedagogisk tidsskrift, 104(3), 226-240. https://doi.org/10.18261/issn.1504-2987-2020-03-02

Lyngstad, I. \& Sæther, E. (2021). The concept of 'friluftsliv literacy' in relation to physical literacy in physical education pedagogies. Sport, Education and Society, 26(5), 514-526. https://doi.org/10.1080/13573322. 2020.1762073

Moen, K. M., Westlie, K., Bjørke, L. \& Brattli, V. H. (2018). Når ambisjon møter tradisjon: En nasjonal kartleggingsstudie av kroppsøvingsfaget i grunnskolen (5.-10. trinn) (Rapport 1-2018). Høgskolen i Innlandet.

Monsen, L. (2017). Med fiskestang og svartkjele. Hva villmarka lerte meg. Cappelen Damm.

Monsen, L. (1994). Med fiskestang og svartkjele. Hva villmarka lerte meg. Naturforlaget.

Murud, M. M. E. (2018). Dollagáttis/Ved bålet. Bárus.

NDLA. (2019). Bålet. https://ndla.no/nb/subject:26/topic: $1: 4208 /$ topic: $1: 191186 /$ resource: $1: 16726$ ?filters=urn: filter:fa2a7d6a-5e8e-4976-82c0-9a1266684c1c

NDLA. (2012). Ler å tenne bål på en riktig måte. https://ndla.no/nb/subject:26/topic:1:4208/topic:1:191186/res ource: 1:9187?filters=urn:filter:fa2a7d6a-5e8e-4976-82c0-9a1266684c1c

Quennerstedt, M. (2019). Physical education and the art of teaching: Transformative learning and teaching in physical education and sports pedagogy. Sport, Education and Society, 24(6), 611-623. https://doi.org/10. 1080/13573322.2019.1574731

Quennerstedt, M. \& Larsson, H. (2015). Learning movement cultures in physical education practice. Sport, Education and Society, 20(5), 565-572. https://doi.org/10.1080/13573322.2014.994490

Ryd, Y. (2018). Bål-samisk ildkunst. Dreyers forlag.

Svardal, T. (2015). Bål-for all slags vcer og terreng. Kagge forlag.

Sølvik, R. M. (2013). Friluftsliv som sosialt laringslandskap for ungdom i risiko: Eit fenomenologisk-inspirert kasusstudium [Doktoravhandling]. Universitetet i Oslo.

Tordsson, B. (2014). Perspektiv på friluftslivets pcedagogik. BoD-Books on Demand.

Utdanningsdirektoratet. (2015). Lereplan i kroppsøving. https://www.udir.no/k106/KRO1-04

Winge, K. \& Nohr, A. (2019). Mat på bålet. Vigmostad Bjørke.

Öhman, J. (2014). Om didaktikens möjligheter: Ett pragmatiskt perspektiv. Utbildning E Demokrati, 23(3), 33-52. https://doi.org/10.48059/uod.v23i3.1023

Østrem, K. (Red.). (2021). Ncermiljøfriluftsliv i skolen. Cappelen Damm Akademisk. 